ABDI: Jurnal Pengabdian dan Pemberdayaan Masyarakat ISSN: 2656-369X (Print), 2684-8570 (Online)

Volume 3 No. 2, Desember 2021

http://abdi.ppj.unp.ac.id/index.php/abdi

Email: abdi@ppi.unp.ac.id

DOI: https://doi.org/10.24036/abdi.v3i2.111

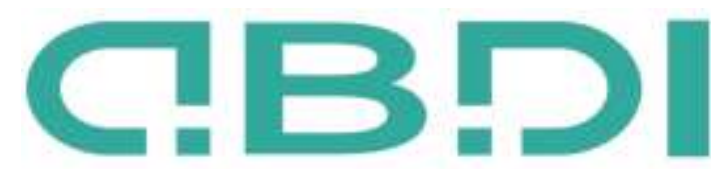

ABDE JURNAL PENGABDIAN DAN PEMBERDAYMN MUSYARAKAT

\title{
Video Iklan Sebagai Sarana Peningkatan Impresi Publik Terhadap Produk Komunitas UMKM Kotabaru Yogyakarta
}

\author{
Clara Hetty Primasari ${ }^{1}$, Yohanes Priadi Wibisono ${ }^{2}$ \\ ${ }^{1,2}$ Program Studi Sistem Informasi, Universitas Atma Jaya Yogyakarta \\ E-mail: clara.hetty@uajy.ac.id,priadi.wibisono@uajy.ac.id
}

\begin{abstract}
Abstrak
Konten iklan yang digunakan oleh Pelaku UMKM Kotabaru selama ini kebanyakan menggunakan konten iklan visual statis seperti foto dan poster. Konten iklan visual memiliki keunggulan yaitu lebih cepat dilihat dalam hitungan detik, namun memiliki kekurangan yaitu pada terbatasnya materi yang disampaikan. Selain itu, saat ini iklan dengan gambar statis dirasa kurang menarik minat konsumen untuk mengujungi atau memfollow akun media sosial UMKM. Akan lebih menarik jika iklan di media sosial disajikan dalam bentuk video. Mitra menyadari kemampuan dalam memproduksi video yang berkualitas dan estetik masih sangat kurang. Mitra juga tidak memiliki cukup waktu untuk membuat Video iklan tersebut. Untuk itu, Tim Pengembangan Sosial Ekonomi Kotabaru meminta bantuan kepada Tim Pengabdian UAJY untuk melakukan pembuatan Video Iklan untuk anggota UMKM Kotabaru. Dari pengabdian ini dihasilkan video iklan yang diunggah ke media social dan terbukti dapat meningkatkan impresi public terhadap produk UMKM Kotabaru.
\end{abstract}

Kata kunci: Iklan, Media sosial, Online, UMKM, Video

\section{Abstract}

The advertising content used by UMKM Kotabaru has mostly used static visual ad content such as photos and posters. Visual ad content has the advantage that it is faster to view in seconds, but has a disadvantage, namely the limited material presented. In addition, ads with static images are deemed less attractive to consumers to visit or follow MSME social media accounts. It would be more interesting if advertisements on social media were presented in the form of videos. Partners are aware that the ability to produce quality and aesthetic videos is still lacking. Partners also do not have enough time to create a Video of the ad. For this reason, the Kotabaru Socio-Economic Development Team requested assistance from the UAJY Service Team to make video and clip advertisements for Kotabaru UMKM members. Video ads are uploaded to social media and are proven to increase public impression of Kotabaru UMKM products.

Keyword: Advertisement, MSME, Online, Social media, Video

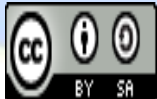

Received: 10 Mei 2021

Revised: 5 Agustus 2021

Available Online: 25 Agustus 2021 
Clara Hetty Primasari, Yohanes Priadi Wibisono Video Iklan Sebagai Sarana Peningkatan Impresi Publik Terhadap Produk Komunitas UMKM Kotabaru Yogyakarta

\section{Pendahuluan}

Kemajuan di bidang teknologi, komputer, dan telekomunikasi mendukung perkembangan teknologi internet. Dengan internet pelaku bisnis tidak lagi mengalami kesulitan dalam memperoleh informasi apapun, untuk menunjang aktivitas bisnisnya, bahkan sekarang cenderung dapat diperoleh berbagai macam informasi, sehingga informasi harus disaring untuk mendapatkan informasi yang tepat dan relevan (Wibowo, 2016). Perkembangan dan jumlah pengguna internet yang terus bertambah dari tahun ke tahun menjadikan internet menjadi salah satu alat untuk komunikasi, hiburan, edukasi, dan penjualan elektronik (Eka Santi, 2020). Pada Januari 2021, tercatat terdapat 202,6 juta pengguna internet di Indonesia (We Are Social, 2021). Internet telah muncul sebagai media periklanan. Para pelaku bisnis menggunakan internet untuk mengiklankan produk dan jasa mereka (Lau et al., 2011). Internet dianggap sebagai saluran pemasaran yang paling signifikan untuk pasar global sehingga perusahaan mengeluarkan biaya cukup besar untuk membangun iklan di internet sebagai bentuk investasi mereka. Pemasaran secara online ini juga memiliki banyak keuntungan seperti dapat menjangkau konsumen lebih efektif, biaya yang efektif, hasilnya dapat diukur, dan dapat dipersonalisasikan (Bagas et al., 2021). Namun terdapat kontrak dari online marketing yaitu tingkat kompetisi yang sangat tinggi (Schwarzl \& Grabowska, 2015).

Saat ini, konsumen yang mayoritas merupakan pengguna internet dan media sosial banyak disuguhi oleh beragam konten iklan yang bertebaran di dunia maya. Konten iklan tersebut beragam bentuknya. Ada yang berupa iklan dengan media visual seperti gambar statis, foto, poster, animasi tanpa suara; atau audio seperti rekaman suara, podcast, hingga media audio visual seperti video dengan suara.

Masing-masing media memiliki keunggulan dan kelemahannya sendiri, tergantung target yang ingin dicapai. Konten iklan visual seperti gambar statis lebih cepat dilihat dalam hitungan detik, menarik karena bisa didesain sedemikian rupa mengikuti konsep dari iklan dan produk yang ditawarkan, namun terbatas dalam hal materi yang disampaikan. Ini dikarenakan konten ditampilkan hanya satu pada satu sisi media visual itu saja. Fungsi visualisasi dalam iklan adalah merebut atensi, mengidentifikasi subyek, center of interest, membangkitkan minat baca headline, memberikan kesinambungan keseluruhan iklan, serta mampu menitikberatkan pada aspek-aspek produk yang lain. Oleh sebab itu, perlunya produsen untuk memperhatikan karakteristik media cetak yang akan dipilih untuk eksekusi iklannya melalui beberapa elemen struktur media cetak seperti headline, subheadline, body copy, slogan. Selain itu, untuk menghasilkan konten iklan visual yang menarik, diperlukan sentuhan seni dan kemampuan desain. Konten iklan audio seperti rekaman suara dan podcast mampu menyampaikan beragam informasi dengan lugas, lebih mudah dibuat karena hanya berupa rekaman suara, namun membutuhkan durasi yang lebih Panjang untuk setiap iklannya dan lebih cocok dipasang pada media komunikasi radio. Konten iklan audio visual menggabungkan media visual dan audio sehingga tidak hanya bisa dipandang namun juga bisa didengar. Informasi yang disampaikan melalui media ini bisa lebih banyak dibanding hanya menggunakan media visual statis karena gambar yang ditampilkan tidak hanya 1 frame saja, dan informasi tambahan juga dapat diberikan dengan penjelasan via audio.

Sementara gambar membantu memperkuat kata-kata dan isi pesan yang berorientasi identitas, Pembuatan video merupakan metode paling ampuh untuk menciptakan kesan mental yang kuat tentang suatu produk di benak publik (Brown et al., 2005). Video meningkatkan kesan publik terhadap produk, menempatkan wajah manusia pada suatu produk, dan pada akhirnya membangun merek. Tiga $\mathrm{V}$ komunikasi yaitu verbal, vokal, dan visual, disatukan dalam bentuk video sehingga penonton terpengaruh pada bentuk komunikasi yang sedang disampaikan (Waters \& Jones, 2011). Ketiga karakteristik komunikasi ini ternyata memiliki pengaruh terkuat pada penerima pesan dalam hal mengingat pesan utama (Hall \& Schmid Mast, 2007).

UMKM Kotabaru telah melaksanakan promosi iklan melalui Katalog Digital UMKM dan melalui media social seperti Instagram dan facebook (Primasari et al., 2020). Pada media periklanan tersebut konten iklan yang digunakan adalah konten iklan visual berupa gambar statis seperti foto dan poster. Foto-foto pada katalog dapat dilihat pada Gambar 1 dan 2, sedangkan poster dapat dilihat pada Gambar 3. 
Clara Hetty Primasari, Yohanes Priadi Wibisono Video Iklan Sebagai Sarana Peningkatan Impresi Publik Terhadap Produk Komunitas UMKM Kotabaru Yogyakarta

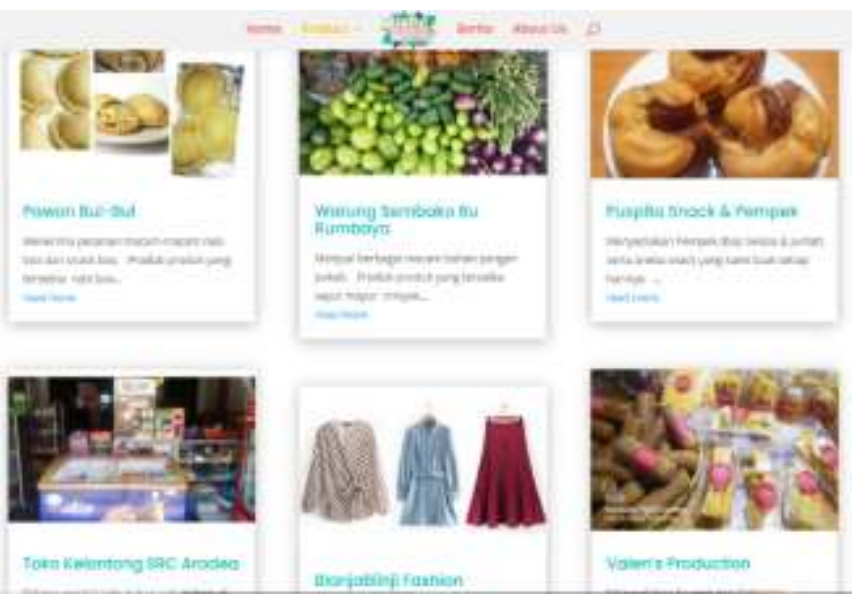

Gambar 1. Katalog Digital UMKM Kotabaru
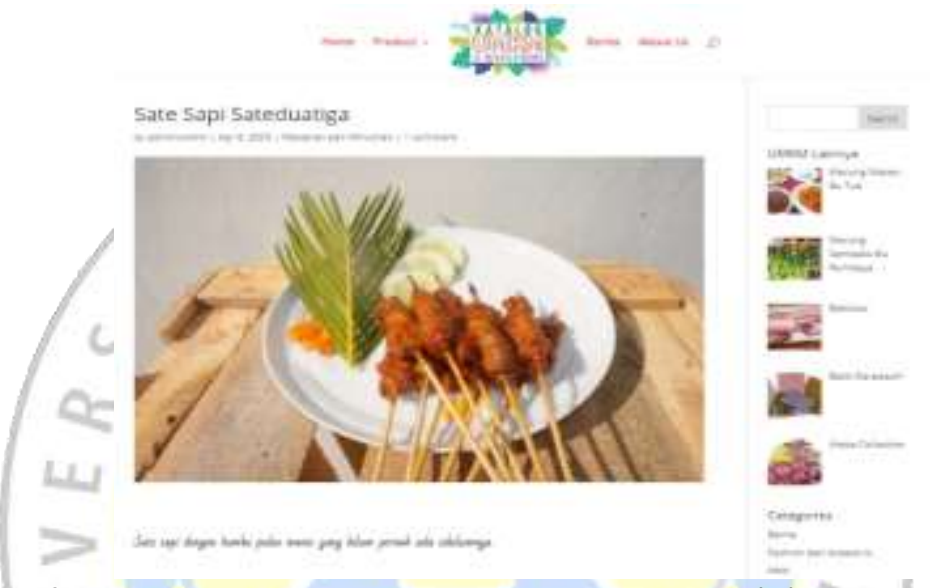

\section{Gambar 2. Foto salah satu UMKM dalam Katalog Digital UMKM Kotabaru}

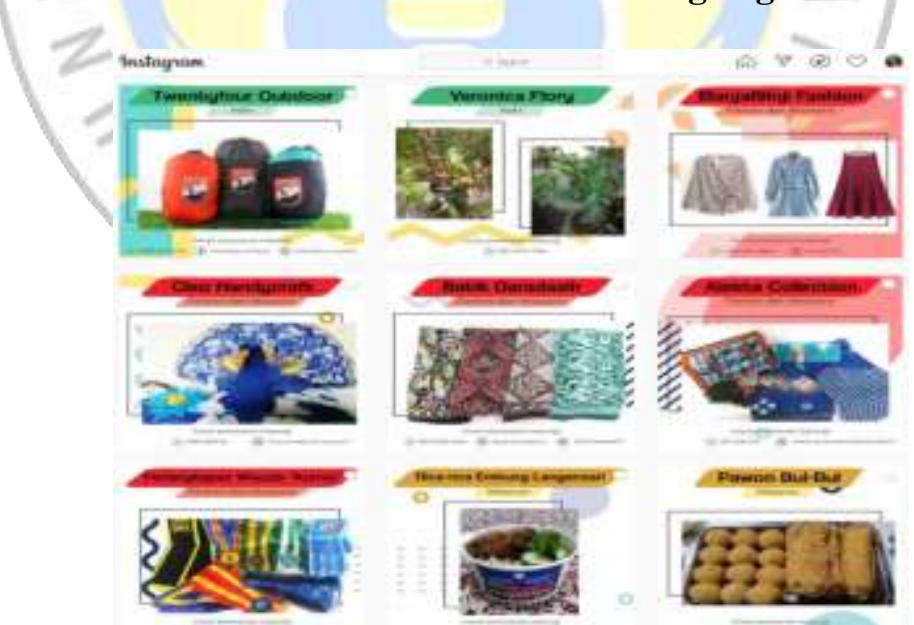

Gambar 3. Poster tiap UMKM dalam Instagram @ umkmkobar

Katalog UMKM Kotabaru dapat diakses pada alamat https://umkmkobar.com/, Instagram dan Facebook dengan username @ umkmkobar. Katalog dan Pemasaran Online yang telah dilakukan telah memberi manfaat kepada beberapa Anggota komunitas UMKM St. Antonius Padua Kotabaru yang kini berjumlah 74 UMKM dan masih terus bertambah. Produk mereka telah lebih dikenal oleh Umat Paroki Kotabaru pada khususnya dan masyarakat luas pada umumnya.

Iklan dengan gambar statis dirasa kurang menarik minat konsumen untuk mengujungi atau memfollow akun media sosial UMKM. Selain itu, Mitra menyadari kemampuan dalam memproduksi 
Clara Hetty Primasari, Yohanes Priadi Wibisono Video Iklan Sebagai Sarana Peningkatan Impresi Publik Terhadap Produk Komunitas UMKM Kotabaru Yogyakarta

video yang berkualitas dan estetik masih sangat kurang dan Mitra sendiri lebih berfokus pada kegiatan utama PSE, sehingga tidak memiliki cukup waktu untuk membuat Video iklan tersebut. Ditambah lagi dengan kondisi pandemic juga membuat penjualan dan omset pelaku UMKM di lingkungan Paroki St. Antonius Kotabaru berkurang. Beberapa alasan di atas mendorong Tim Pengembangan Sosial Ekonomi (PSE) Kotabaru meminta bantuan kepada Tim Pengabdian UAJY untuk melakukan pembuatan Video Iklan untuk masing-masing anggota UMKM Kotabaru. Pengabdian Pembuatan Video Iklan ini merupakan kelanjutan dari Program Tim PSE Kotabaru antara lain Acara Temu Kenal UMKM Kotabaru, penyelenggaraan Bazaar UMKM Kotabaru, pengabdian pembuatan katalog fisik dan digital UMKM yang telah selesai dilaksanakan pada Februari 2020, dan pengabdian Social Media Marketing yang telah selesai dilaksanakan pada Juli 2020. Antusiasme mitra terhadap pengabdian pembuatan katalog fisik dan digital serta Social Media Marketing membuat mitra tertarik untuk melanjutkan program kerja sama dengan Tim Pengabdian UAJY. Diharapkan dengan partisipasi umat dan pelaku UMKM, seluruh kegiatan dapat dilaksanakan dengan baik dan menunjang tujuan dari Tim Pendampingan UMKM Kotabaru sendiri.

\section{Metode Pelaksanaan}

\subsection{Metode}

Metode yang digunakan berupa perkenalan dan sosialisasi serta pembuatan video iklan. Materi perkenalan dan sosialisasi pemasaran melalui video meliputi: Definisi Video Iklan, Latar belakang pentingnya Video Iklan, Manfaat Video Iklan, Bagaimana membuat Video Iklan yang menarik, Pemasaran dengan paid promote menggunakan Instagram dan Facebook Business. Peran mitra di sini adalah sebagai peserta perkenalan dan sosialisasi serta penyedia data yang dibutuhkan. Peserta sosialisasi ini adalah Pelaku UMKM di wilayah Paroki St. Antonius Kotabaru. Karena kondisi pandemi ini maka sosialisasi dilaksanakan secara online melalui Zoom. Pengumpulan data untuk iklan dilakukan dengan model wawancara dan meminta Pelaku UMKM untuk mengirimkan data terbaru dari usaha mereka dan membuat janji temu untuk melakukan perekaman video. Berikutnya Tim Pengabdian akan melakukan kunjungan pada tiap UMKM untuk melakukan peliputan dan perekaman video. Peliputan akan dilakukan dengan mengikuti protokol kesehatan COVID-19. Setelah pembuatan konten iklan selesai, dilakukan pemasangan iklan di media sosial dan paid promote iklan tersebut agar jangkauan iklan sesuai dengan target market UMKM.

\subsection{Tahapan dan Luaran}

Pelaksanaan kegiatan Pengabdian Masyarakat ini dibagi kedalam 3 tahap yaitu tahap Persiapan, tahap Pelaksanaan dan tahap Pelaporan. Rincian kegiatan dan luarannya dapat dilihat pada Tabel 1.

Tabel 1. Tahapan dan Luaran Kegiatan

\begin{tabular}{|c|c|c|}
\hline No. & Kegiatan & Luaran \\
\hline & Tahap Persiapan & \\
\hline 1 & Mempersiapkan rencana pengabdian & Dokumen rencana pengabdian \\
\hline \multirow[t]{2}{*}{2} & $\begin{array}{l}\text { Mempersiapkan materi untuk perkenalan } \\
\text { dan sosialisasi Video Iklan }\end{array}$ & Materi perkenalan dan sosialisasi awal \\
\hline & Tahap Pelaksanaan & \\
\hline 3 & $\begin{array}{l}\text { Perkenalan dan } \\
\text { pengumpulan Data UMKM dan janji temu }\end{array}$ & Data UMKM dan list janji temu \\
\hline 4 & Peliputan dan Perekaman Video & Raw material \\
\hline 5 & Editing Video & Video Iklan \\
\hline \multirow[t]{2}{*}{6} & Pengunggahan konten iklan digital & $\begin{array}{l}\text { Video Iklan yang telah dipublikasikan pada } \\
\text { Sosial Media dan Youtube }\end{array}$ \\
\hline & Tahap Pelaporan & \\
\hline 7 & Penyusunan laporan akhir & Laporan PPM final \\
\hline 8 & Membuat artikel untuk publikasi & Artikel Publikasi \\
\hline
\end{tabular}


Clara Hetty Primasari, Yohanes Priadi Wibisono Video Iklan Sebagai Sarana Peningkatan Impresi Publik Terhadap Produk Komunitas UMKM Kotabaru Yogyakarta

\section{Hasil dan Pembahasan}

Pelaksanaan kegiatan pengabdian kepada masyarakat dari Bulan Oktober - Desember 2020 menghasilkan beberapa kegiatan dan luaran antara lain:

\subsection{Kegiatan Perkenalan dan Sosialisasi}

Kegiatan perkenalan dan sosialisasi Video dilaksanakan secara daring melalui aplikasi Zoom. Acara ini dihadiri oleh 24 umat Paroki St. Antonius Kotabaru. Pada acara ini dicatat umat yang usahanya ingin dibuatkan video marketingnya dan penentuan waktu untuk pengambilan video. Dokumentasi kegiatan dapat dilihat pada Gambar 4.

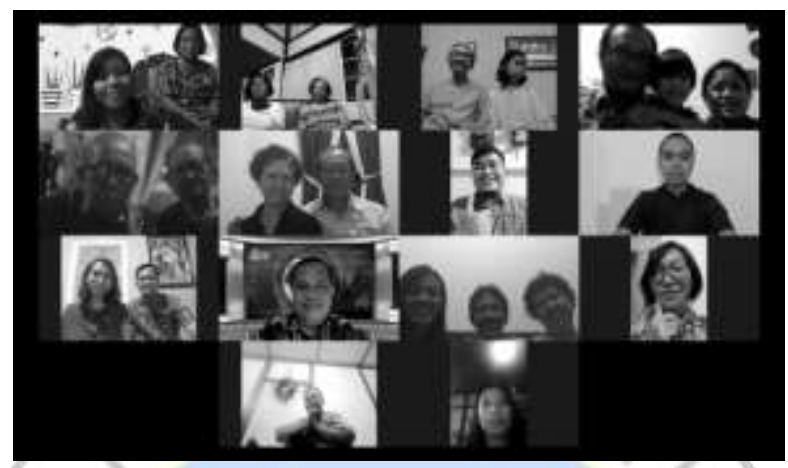

Gambar 4. Dokumentasi Kegiatan Perkenalan dan Sosialisasi

\subsection{Kunjungan Peliputan UMKM}

Kunjungan Peliputan UMKM untuk merekam video dari masing-masing usaha UMKM dilakukan pada bulan November 2020.

\subsection{Pembuatan dan Pemasangan Video pada Sosial Media}

Pembuatan dan pengeditan video dilakukan pada Bulan Desember 2020. Setelah video selesai dibuat, video diupload pada akun Instagram masing-masing UMKM untuk di-paid promote. Salah satu video yang dihasilkan dan diunggah pada Instagram ditunjukkan pada Gambar 5.

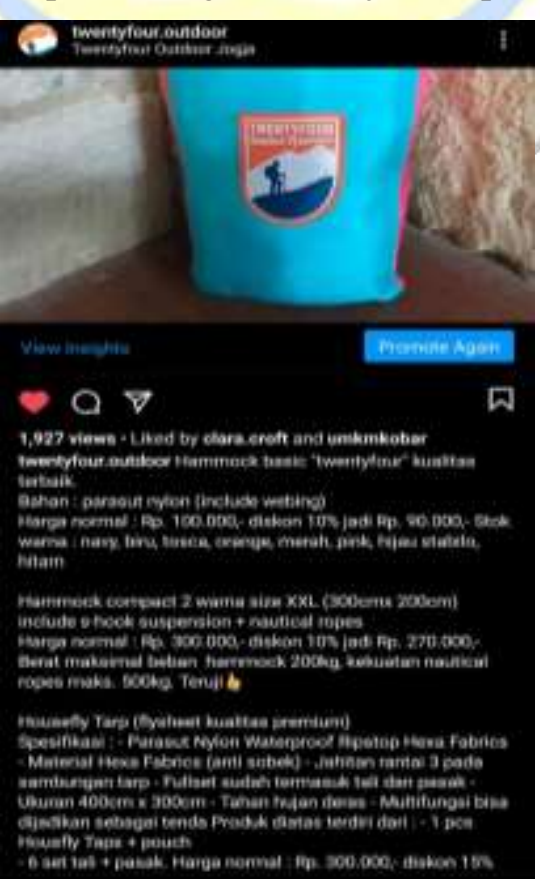


Clara Hetty Primasari, Yohanes Priadi Wibisono Video Iklan Sebagai Sarana Peningkatan Impresi Publik Terhadap Produk Komunitas UMKM Kotabaru Yogyakarta

\section{Gambar 5. Contoh Video yang diunggah pada Instagram salah satu UMKM}

Pada Gambar 6 dapat dilihat Post Insight dari suatu produk UMKM yang dibuat kontennya dalam bentuk video maupun foto. Like adalah jumlah akun yang menyukai postingan, follow adalah jumlah akun baru yang memfollow (mengikuti) akun umkm setelah melihat postingan iklan, reach adalah jumlah akun unik yang telah melihat postingan iklan tersebut, profile visit adalah jumlah kunjungan profil Instagram setelah melihat postingan iklan, sedangkan impression adalah berapa kali postingan telah tampil di layar pengguna, Pada postingan video diperoleh 26 like, 0 komentar, 0 share, 0 save, 5 profile visit, 500 reach, 5 action, 0 follow, dan 531 impression. Sedangkan pada postingan foto diperoleh 18 like, 1 komentar, 0 share, 10 save, 0 profile visit, 0 action, 59 reach, 0 follow, dan 62 impression.

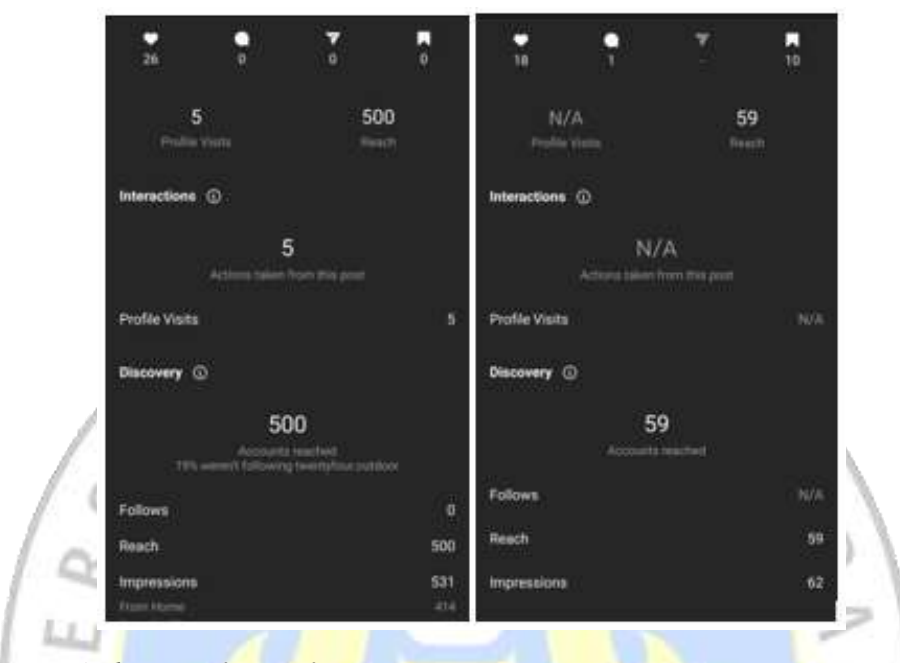

\section{Gambar 6. Post Insight Posting Video vs Foto pada produk yang sama tanpa dipromote}

Terdapat selisih jumlah like sebesar $44 \%$, reach sebesar $747 \%$, dan impression sebesar $756 \%$. Kenaikan ini menandakan iklan dalam bentuk video lebih efektif dalam meningkatkan like, reach, dan impression dari posting iklan. Tidak berhenti pada pembuatan dan pengunggahan video pada sosial media. Video juga didaftarkan pada jasa paid promote dari Instagram. Paid promote kami lakukan dengan harapan postingan akan semakin luas jangkauan dan visibilitasnya. Sebelum dilakukan paid promote, jumlah like, follow, reach, profile visit yang diperoleh dapat dilihat pada Gambar 8 (kiri).

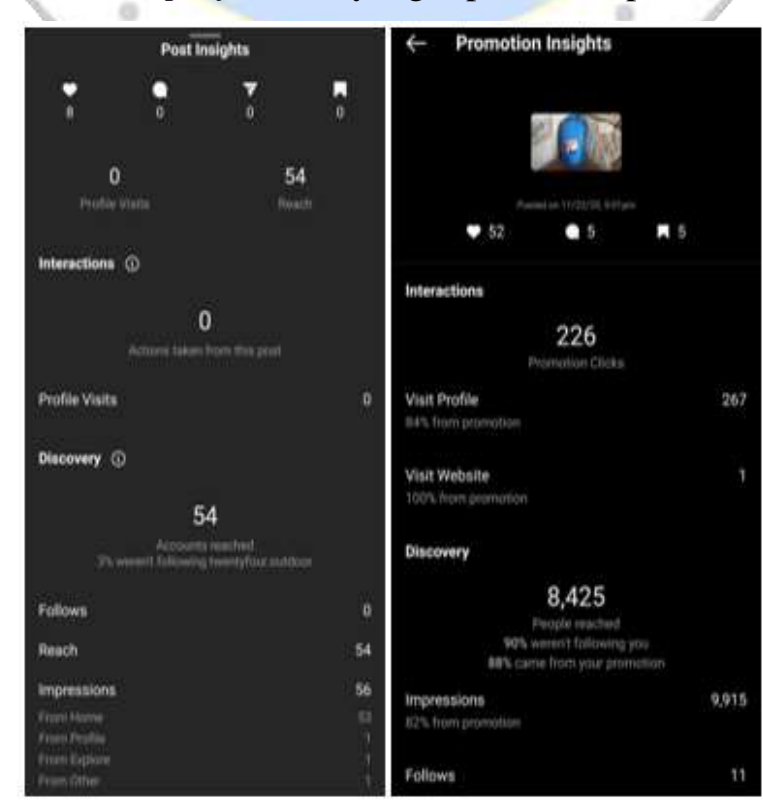


Clara Hetty Primasari, Yohanes Priadi Wibisono Video Iklan Sebagai Sarana Peningkatan Impresi Publik Terhadap Produk Komunitas UMKM Kotabaru Yogyakarta

\section{Gambar 7. Post Insight Posting Video sebelum dan sesudah dipromote}

Post insight pada Gambar 7 kami capture beberapa menit setelah postingan dipublish. Kami menggunakan postingan yang berbeda dari postingan pada Gambar 6. Dari Gambar 7 dapat diketahui bahwa respon dari pengguna Instagram masih sangat terbatas. Terdapat 8 like, 0 follow, 54 reach, 0 profile visit, dan 56 impression.

Setelah dilakukan paid promote pada Instagram selama 3 hari dengan budget perhari Rp 20.000 dengan pilihan target audiens sesuai dengan yang direkomendasikan Instagram (automatic), diperoleh hasil seperti yang ditunjukkan pada post insight Gambar 7 (kanan). Diperoleh 52 like, 5 komentar, 5 kali save, 226 klik pada postingan, 267 kunjungan pada profil, 1 kunjungan pada website, 8425 reach, 9915 impression, dan 11 follower baru pada akun Instagram.

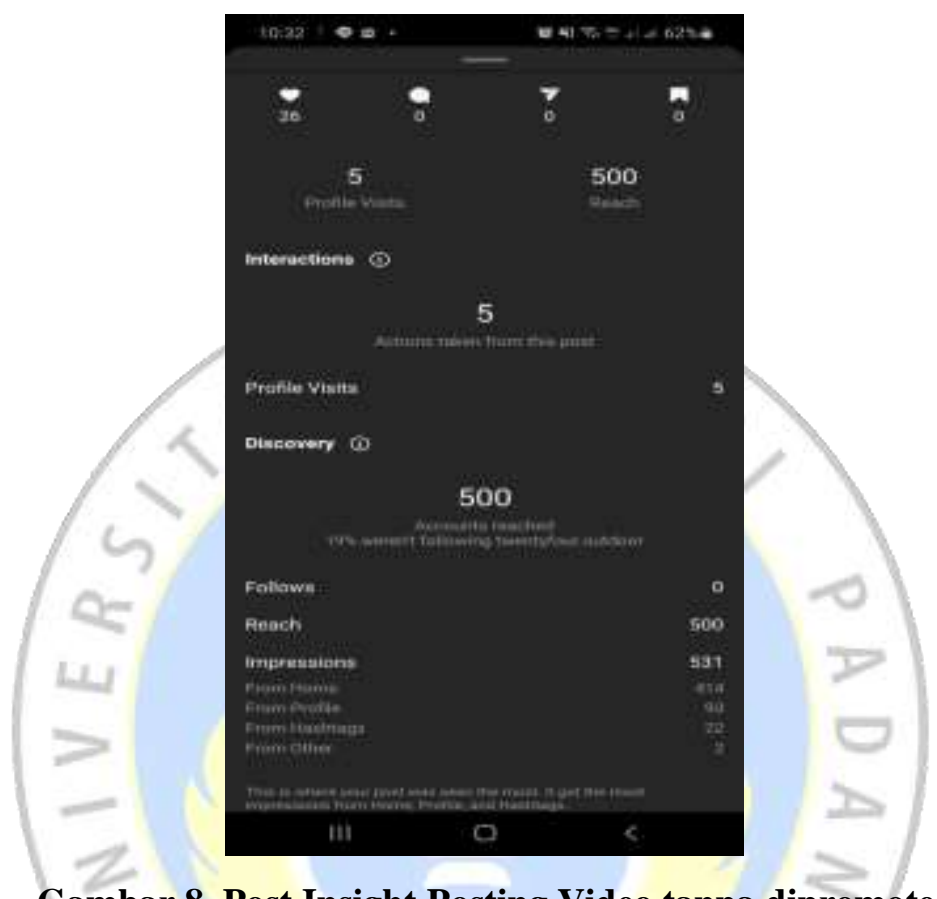

Gambar 8. Post Insight Posting Video tanpa dipromote

Sebagai perbandingan kami juga menampilkan post insight dari postingan video yang sama yang tidak dikenai paid promote. Post insight tersebut dapat dilihat pada Gambar 8. Pada kondisi tanpa dikenai paid promote, postingan hanya meraih 26 like, 0 komentar, save, dan share, 5 kunjungan profil, 500 reach dan 531 impression. Dari data ini dapat disimpulkan bahwa terjadi selisih like sebesar 50\%, kunjungan profil sebesar $5240 \%$, reach sebesar $1585 \%$, impression sebesar $1767 \%$ dari postingan yang sama dengan perbedaan perlakukan dengan dan tanpa paid promote.

\section{Kesimpulan}

Dari hasil dan pembahasan pada bagian sebelumnya, dapat ditarik kesimpulan bahwa pembuatan video iklan dan paid promote efektif untuk meningkatkan insight impresi public dari iklan pada sosial media instagram. Insight yang mengalami kenaikan antara lain jumlah like, reach, komentar, save, klik pada postingan, kunjungan profil, kunjungan pada website, reach, follower, dan impression pengguna Instagram pada iklan yang ditayangkan. Pengabdian ini masih memiliki keterbatasan yaitu belum mengukur hubungan dari kenaikan insight iklan video dengan kenaikan omset yang diterima UMKM. Hal ini bisa menjadi saran pada pengabdian atau penelitian selanjutnya untuk dapat mengukur hubungan tersebut. 
Clara Hetty Primasari, Yohanes Priadi Wibisono Video Iklan Sebagai Sarana Peningkatan Impresi Publik Terhadap Produk Komunitas UMKM Kotabaru Yogyakarta

\section{Daftar Pustaka}

Bagas, A., Irianto, P., \& Primasari, C. H. (2021). Pemberdayaan Organisasi Nirlaba dalam Memanfaatkan Website Media Sosial dan Promosi Potensi Ekonomi Desa. MATAPPA : Jurnal Pengabdian Kepada Masyarakat, 4(2), 276-281.

Brown, J. S., Prusak, L., Denning, S., \& Groh, K. (2005). Storytelling in organizations: Why storytelling is transforming 21 st century organizations and management. Elsevier Butterworth-Heinemann.

Eka Santi, D. (2020). Peran Online Advertising Pada Pemasaran Axis. SOURCE: Jurnal Ilmu Komunikasi, 6(1), 58-71.

Hall, J. A., \& Schmid Mast, M. (2007). Sources of accuracy in the empathic accuracy paradigm. Emotion, 7(2), 438.

Lau, T. C., Lim, Y.-M., \& Yap, C.-S. (2011). The Effectiveness of Online Advertising in Purchase Decision: Liking, Recall and Click. Australian Journal of Basic and Applied Sciences, 5(9), $1517-1524$.

Primasari, C. H., Wibisono, Y. P., \& Padawangi, T. Q. (2020). Sosial Media Marketing Sebagai Sarana Peningkatan Kualitas Pemasaran Komunitas Umkm Paroki St. Antonius Kotabaru Yogyakarta. IKRA-ITH ABDIMAS, 3(3), 97-101.

Schwarzl, S., \& Grabowska, M. (2015). Online marketing strategies: the future is here. Journal of International Studies, 8(2), 187-196.

Waters, R. D., \& Jones, P. M. (2011). Using Video to Build an Organization's Identity and Brand: A Content Analysis of Nonprofit Organizations' YouTube Videos. Journal of Nonprofit \& Public Sector Marketing, 23(2), 248-268.

We Are Social, \& H. (2021). Digital 2021. Global Digital Insights.

Wibowo, E. A. (2016). Pemanfaatan Teknologi E-Commerce dalam Proses Bisnis. Equilibiria, 1(1), 110.

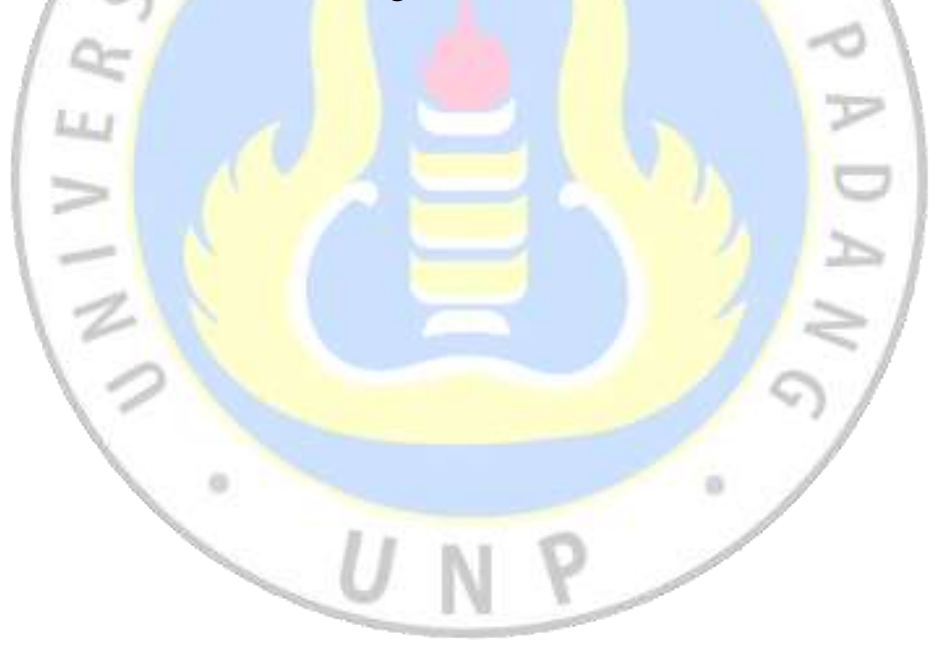

